\title{
Efektivitas Penerapan Pembelajaran Daring dengan Platform Google Classroom Pada Mata Pelajaran PJOK
}

\author{
I Made Mahendra ${ }^{1 *}$ \\ 1,2,3 Jurusan Pendidikan Olahraga, Universitas Pendidikan Ganesha Singaraja, Indonesia
}

\section{ARTICLE IN F O}

\section{Article history:}

Received June 04, 2021

Revised June 09, 2021

Accepted July 07, 2021

Available online July 25, 2021

Kata Kunci:

Efektiviatas, Platform Google

Classroom, PJOK

Keywords:

Effectiveness, Google Classroom Platform, PJOK

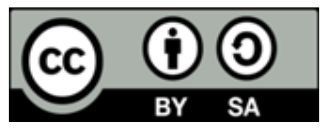

This is an open access article under the CC BY-SA license.

Copyright $(2021$ by Author. Published by Universitas Pendidikan Ganesha.

\begin{abstract}
A B S T R A K
Penelitian ini bertujuan untuk mengetahui efektivitas penerapan pembelajara daring dengan platform google classroom pada mata pelajaran PJOK di SMA Negeri 3 Singraja. Penelitian ini adalah penelitian deskriftif kuantitatif dengan jenis penelitian survei. Populasi dalam penelitian ini adalah peserta didik SMA Negeri 3 Singaraja dengan jumlah keseluruhan 1041 orang. Sampel penelitian ini menggunakan teknik random sampling dengan quota sampling sebanyak $10 \%$ dari total populasi sehingga jumlah sampel dalam penelitian ini adalah 107 orang. Data dianaisis menggunakan teknik deskriptif kuantitatif dengan mencari persentase. Hasil dalam penelitian ini dilihat dari respon peserta didik terhadap proses pembelajaran daring dengan platform google classroom pada mata pelajaran PJOK dengan nilai persentase keefektifan sebesar $74,3 \%$ ada pada criteria efektif dan nilai output peserta didik sebagai penguat data dengan nilai persentase ketuntasan pembelajaran $75,8 \%$ (tuntas) ada pada katagori efektif. Penerapan pembelajaran daring dengan platform google classroom pada mata pelajaran PJOK dapat dikatakan efektif.
\end{abstract}

\begin{abstract}
A B S T R A K
The COVID-19 pandemic has had a tremendous impact on the world of education. The pandemic forced the learning process to change from face-to-face to online learning. Online learning requires teachers to be smart in choosing and using learning media and technology in delivering learning materials. This study aims to determine the effectiveness of the application of online learning with the google classroom platform on PJOK subjects. This research is descriptive quantitative research with the type of survey research. The population in this study were participants with a total of 1041 students. The sample of this study used a random sampling technique with quota sampling as much as $10 \%$ of the total population so that the number of samples in this study was 107 students. Data was collected using assessment instruments in the form of questionnaires and documentation. After the data was collected, the data was analyzed using quantitative descriptive techniques by looking for percentages. The results in the study indicate that the response of students to the online learning process with the google classroom platform on PJOK subjects with an effectiveness percentage value of $74.3 \%$ is in the effective criteria and the output value of students as data reinforcement with a learning completeness percentage value of $75.8 \%$. (complete) is in the effective category. The application of online learning with the google classroom platform on PJOK subjects can be said to be effective.
\end{abstract}

\section{PENDAHULUAN}

Saat ini Wabah covid-19 telah memberikan dapak yang sangat besar bagi lembaga pendidikan, khususnya lembaga pendidikan di indonesia. Untuk mengantisipasi penularan virus tersebut pemerintah telah mengeluarkan berbagai kebijakan seperti isolasi, social distancing hingga pembatasan sosial berkala besar (Syah, 2020). Kondisi ini menuntut lembaga pendidik untuk melakukan inovasi dalam proses pembelajaran. Salah satu inovasinya adalah dengan menerapkan pembelajran daring (Pujilestari, 2020). Pembelajaran daring memiliki pengertian yang sama dengan e-learning yang dapat didefinisikan sebagai 
aktifitas pembelajaran apapun yang terjadi melalui internet (Prasetya \& Harjanto, 2020). Menurut (Mohammad Yazdi, 2012) Pembelajaran daring merupakan sebuah sistem pembelajaran sebagai aplikasi teknologi informasi yang diterapkan dalam bentuk virtual learning. Pembelajaran daring merupakan salah satu solusi untuk menerapkan social distancing guna mencegah mata rantai penyebaran covid-19. Pembelajaran daring merupakan pembelajaran yang dilakukan secara online dengan jarak jauh atau pembelajaran yang dilakukan peserta didik dimanapun dan kapanpun saat dibutuhkan, sehingga dapat menghindari krumunan yang dianggap sebagai salah satu cara untuk menerapkan social distancing (Wulandari, 2018). Dalam menerapkan pembelajaran daring pendidik harus mampu menggunakan teknologi internet yang dapat mempermudah pendidik dalam memberikan pembelajaran dan memudahkan peserta didik dalam menerima pembelajaran. Selain itu pendidik harus memiliki kemampuan megunakan media seperti laptop dan aplikasi yang digunakan (Pujiasih, 2020). Dengan demikian dapat disimpulkan bahwa Pembelajaran daring merupakan pembelajaran yang dilakukan secara daring melalui jaringan atau koneksi internet untuk menyampaikan materi pembelajaran tanpa dibatasi ruang dan waktu.

Kondisi pembelajaran daring saat ini, peserta didik dan pendidik memanfaatkan perkembangan teknologi informasi yang ada, dengan menggunakan media pembelajaran daring. Salah satu media pembelajaran daring yang dapat digunakan adalah google classroom. Platform google classroom adalah salah satu aplikasi yang dapat digunakan oleh pendidik untuk menerapkan proses pembelajaran daring. Menurut (Ernawati, 2018) Google Classroom merupakan layanan yang berbasis internet yang disediakan oleh google sebagai sebagai ruang kelas dunia maya. (Maesaroh et al., 2019) menyatakan, Google Classroom dirancang untuk membantu pengajar membuat dan mengumpulkan tugas tanpa kertas, termasuk fitur yang menghemat waktu seperti kemampuan untuk membuat salinan dokumen secara otomatis bagi setiap peserta didik. Kelas elektronik ini juga dapat membuat folder penyimpanan untuk setiap tugas dan setiap siswa, agar semuanya tetap teratur. Peserta didik dapat melacak setiap tugas yang hampir mendekati batas waktu pengumpulan di halaman tugas, dan mulai mengerjakannya cukup dengan satu klik. Pengajar dapat melihat dengan cepat siapa saja yang belum menyelesaikan tugas, serta memberikan masukan dan nilai langsung di kelas elektronik. Google classroom adalah sebuah teknologi yang dirancang oleh google untuk mempermudah pendidik dan peserta didik dalam proses pembelajaran didalam kelas maupun diluar kelas dalam membuat, mengembangkan dan menggolongkan setiap penugasan tanpa kertas (Wicaksono, 2020). Dengan demikian, dapat disimpulkan bahwa google classroom adalah aplikasi yang disediakan oleh google untuk membuat ruang pembelajaran atau ruang kelas dalam duania maya untuk membantu pendidik dan peserta didik dalam proses pembelajaran. Pembelajaran dangan menggunakan rancangan kelas yang mengaplikasikan google classroom ramah lingkunagan dikarenakan siswa tidak lagi menggunakan kertas dalam pengumpulan tugasnya. Pemanfaatan google classroom bisa melalui berbagai media berupa alat elektronik seperti komputer dan telepon genggam pendidik dan peserta didik dapat mengunjungi situs https://classroom.google.com atau mengunduh aplikasi melalui playstore di android atau apps store di iOS dengan kata kunci Google Classroom. penggunaan aplikasi tersebut tanpa dipungut biaya, sehingga pemanfaatan digunakan sesuai kebutuhan.

Sama halnya pembelajaran yang berlangsung di SMA Negeri 3 Singaraja, Berdasarkan hasil observasi, saat ini sekolah telah memanfaatkan pengembangan teknologi dalam memberikan materi pembelajaran, tugas, dan informasi lainnya kepada peserta didik. Dalam melangsungkan proses pembelajaran pendidik memanfaatkan media pembelajaran daring yaitu google classroom sebagai perantara antara pendidik dengan peserta didik. Penggunaan google classroom merupakan sebuah hal yang baru bagi peserta didik dan guru di lingkunagan sekolah, oleh karena itu terdapat kendala yang dihadapi oleh pendidik dalam proses pembelajaran yaitu, beberapa peserta didik masih belum paham tentang cara menggunakan platform google classroom karena peserta didik masih belum memiliki budaya belajar secara daring. Kesulitan belajar daring ini dikarenakan selama ini proses pembelajaran dilakukan dengan tatap muka atau secara luring sehingga peserta didik belum fasih menggunakan google classroom dalam proses pembelajaran khususnya dalam pembelajaran PJOK. Menurut (Kanca \& Wijaya, 2018) menyatakan bahwa, Pendidikan Jasmani Olahraga dan Kesehatan (PJOK) pada dasarnya merupakan bagian integral dari pendidikan, memiliki tugas yang unik yaitu menggunakan gerak sebagai media untuk pembelajaran peserta didik. Tujuan PJOK tidak hanya mengembangkan ranah jasmani, tetapi juga mengembangkan seluruh potensi peserta didik secara utuh termasuk ranah kognitif dan ranah afektif. Menurut (Habibi, 2020) menyatakan, PJOK adalah suatu proses pendidikan yang dilakukan secara sadar dan sistematik melalui berbagai kegiatan jasmani untuk memperoleh pertumbuhan jasmani, kesehatan jasmani kemampuan dan keterampilan, kecerasan dan perkembangan watak serta kepribadian yang harmonis dalam rangka pembentukan manusia. PJOK adalah pendidikan yang sangat bermnfaat bagi aktifitas peserta didik dimana dalam proses pembelajaran PJOK dapat mengembangkan individu dalam segi organik koknitif dan emosional. PJOK merupakan suatu proses pembelajaran melalui aktivitas 
jasmani yang didesain untuk meningkatkan kebugaran jasmani, pengetahuan dan perilaku hidup sehat dan kecerdasan emosi (Mashud, 2019). Menurut (Kemendikbud, 2017) menyatakan bahwa PJOK merupakan bagian integral dari pendidikan secara keseluruhan, yang bertujuan untuk mengembangkan aspek kebugaran jasmani, keterampilan gerak, keterampilan berfikir kritis, keterampilan sosial, penalaran, stabilitas emosional, tindakan moral, aspek pola hidup sehat, dan pengenalan lingkungan bersih melalui jasmani.

Dari beberapa pengertian tentang PJOK dapat disimpulkan bahwa PJOK merupakan mata pelajaran yang mencangkup seluruh aspek pendidikan dengan rancangan yang sistematis serta mencapai tujuan pendidikan nasional. Aspek yang terkandung dalam mata pelajaran PJOK diantaranya, aspek kebugaran jasmani, pola hidup sehat, keterampilan gerak, keterampilan sosial, berpikir kritis, serta stabilitas emosional. PJOK tidak hanya menuntut siswa untuk berpikir secara individu dalam menyelesaikan masalah, namun siswa juga dituntut untuk aktif di lapangan serta mampu untuk bekerjasama dengan kelompok. Berdasarkan penjabaran latar belakang di atas, maka peneliti tertarik untuk melaksanakan penelitian dengan judul efektivitas penerapan pembelajaran daring dengan platform google classroom pada mata pelajaran PJOK di SMA Negeri 3 Singaraja, dimana dalam penelitian ini bertujuan untuk mengetahui bagaimana efektivitas penerapan pembelajaran daring dengan platform google classroom pada mata pelajaran PJOK di SMA Negeri 3 Singaraja tahun pelajaran 2020/2021.

\section{METODE}

Penelitian ini merupakan penelitian deskriptif kuantitatif. Dalam penelitian ini peneliti tidak memberikan perlakuan, tetapi langsung mengambil data dari sumber data. Penelitian ini dirancang untuk mendeskripsikan dan menjelaskan tentang efektivitas penerapan pembelajaran daring dengan platform google clasroom pada mata pelajaran PJOK di SMA Negeri 3 Singaraja. Penelitian dirancang melalui dari tahap 1) perencanaan yang terdiri dari tahap analisis kebutuhan dan adaptasi intrumen, 2) pelaksanaan yang terdiri atas tahap pengumpulan data, analisis data dan pembahasan, serta 3) pelaporan. Pada tahap persiapan akan dilakukan penyusunan intrumen penelitian. Intrumen penelitian ini meliputi test. Kemudian pada tahap pelaksanaan penelitian dilakukan pengambilan data menggunakan intrumen yang sudah disiapkan pada tahap perencanaan. Test diberikan kepada kelas sampel yang ditentukan secara random sampling. Setelah pemberian test data yang dikumpul akan ditabulasi dan dianalisis. Kemudian kegiatan pada tahap pelaporan meliputi analisis data secara keseluruhan dan perumusan simpulan, serta pembuatan laporan hasil penelitian. Populasi adalah keseluruhan himpunan objek dengan ciri yang sama, populasi dapat berupa himpunan orang, benda, kejadian kasual,waktu atau tempat dengan sifat dan ciri yang sama (Kanca, 2010:19). Dalam penelitian ini, Populasi mencangkup seluruh peserta didik SMA N 3 Singaraja. Pemilihan subjek peserta didik SMA N 3 Singaraja

Tetapi apabila subjek penelitian lebih dari 100, dapat diambil antara $10 \%-15 \%$ atau $20 \%-25 \%$ atau lebih. Dalam penelitian ini pengambilan sampel menggunakan simple random sampling yang dilakukan secara acak dengan diundi. Jumlah sampel dalam penelitian ini adalah 107 peserta didik SMA Negeri 3 Singaraja tahun pelajaran 2020/2021 Pengambilan 10\% dari total populasi yang digunakan sebagai sampel penelitian. Dalam penelitian ini pengumpulan data dilakukan dengan menggunakan instrumen penilaian yang berupa kueioner dan dokumentasi untuk mengidentifikasi efektivitas penerapan pembelajaran online menggunakan platform google classroom pada mata pelajaran PJOK di SMA Negeri 3 Singaraja. Jenis angket yang digunakan dalam penelitian ini adalah angket tertutup yaitu angket yang sudah disediakan jawabannya. Adapun alasan penulis menggunakan angket tertutup karena angket tertutup memberikan kemudahan kepada responden dalam memberikan jawaban, angket tertutup lebih praktis, dan keterbatasan waktu peneliti, sedangkan Instrumen teknik dokumentasi yaitu berupa hasil akhir penilaian yang didapatkan dari guru mata pelajaran PJOK. Teknik analisis data yang digunakan dalam penelitian ini adalah teknik analisis deskriptif kuantitatif untuk menganalisis data secara umum dengan teknik statistik. Analisis bertujuan untuk mengelompokan data sesuai dengan katagori yang ditentukan pada variabel. Analisis ini digunakan pada setiap variabel untuk menentukan persentase. Data yang digunakan untuk mengetahui proses pembelajaran yang efektif disebar menggunakan skala likert dengan menggunakan google form sesuai dengan instrumen penelitian. Proses pembelajaran daring dengan google classroom dianalisis secara deskriptif kuantitatif. Proses pembelajaran efektif atau tidak, dapat dihitung dengan respons peserta didik mengenai proses pembelajaran yang dilakukan. Proses tersebut dilihat dengan Rumus 1 (Nirfayanti \& Nurbaeti, 2019; Puspitasari et al., 2016).

NMR ke- i

$\%$ PRM ke $\mathrm{i}=\overline{\text { NMR Maksimum }} \quad \mathrm{X} 100$ 
Keterangan.

dengan $i$

\%PRM ke $i$

NRM ke $i$

NRM Maksimum

\author{
: Nomor setiap pernyataan (30 pernyataan) \\ : Persentase setiap pernyataan \\ : Nilai respons seluruh peserta didik setiap pernyataan \\ : Nilai maksimum pernyataan (4) x jumlah responden
}

Selanjutnya untuk mengetahui hasil dari kategori proses pembelajaran dengan rumus prsentase kemudian nilai hasil akan di lihat pada tabel kategori yang terdiri dari 5 katagori yaitu sangat efektif, efektif, cukup efektif, tidak efektif dan sangat tidak efektif. Untuk mengetahui ketuntasan pembelajaran peserta didik menggunakan teknik dokumentasi, yaitu hasil nilai penilain akhir semester pada mata pelajaran PJOK. Data tersebut didapatkan langsung dari guru pengampu mata pelajaran PJOK di SMA Negeri 3 Singaraja. Data dianggap berhasil dan pembelajaran dikatakan efektif jika hasil rata-rata nilai peserta didik secara menyeluruh mencapai nilai ketuntasan hasil belajar minimal 55\% dan perorangan mencapai nilai ketuntasan hasil belajar minimal sebesar 75 . kriteria hasil belajar merunjuk pada ketuntasan di SMA Negeri 3 Singaraja. Skor hasil belajar dikatagoriakan dalam bentuk persentase ketuntasan dan kriteria ditunjukkan pada Rumus 2.

$$
P=\frac{F}{N} \times 100
$$

Diamana:

$P$ : persentase

$f$ : frekuensi yang dicari persentase

$\mathrm{N}$ : Jumlah subjek (sampel)

\title{
3. HASIL DAN PEMBAHASAN
}

Dalam penelitian efektivitas Penerapan pembelajaran daring dengan platform google classroom pada mata pelajaran PJOK di SMA Negeri 3 Singaraja dilihat dari proses pembelajaran dan nilai output peserta didik dianalisis menggunakan teknik statistik deskriptif. Dalam penelitian ini akan dicari persentase respon peseta didik terhadap proses pembelajaran dan persentase ketuntasan hasil belajar peserta didik. hasil efetivitas pembelajaran akan dilihat dari kriteria kefektifan pembelajaran yang terdapat 5 katagori yaitu sangat efektif, efektif, cukup efektif, kurang efektif dan sangat kurang efektif. Berikut hasil analisis deskriptif efektivitas penerapan pembelajaran daring dengan platform google classroom pada mata pelajaran PJOK di SMA Negeri 3 Singaraja dilihat dari proses pembelajaran peserta didik dan nilai output peserta didik pada Tabel 2.

Table 2. Analisis data respon peserta didik terhadap proses pembelajaran

\begin{tabular}{|c|c|c|c|c|c|}
\hline Variabel & Aspek & Indikator & $\begin{array}{c}\text { Nilai } \\
\text { persentase } \\
\text { setiap indikator }\end{array}$ & $\begin{array}{c}\text { Nilai } \\
\text { persentase } \\
\text { setiap aspek } \\
\end{array}$ & kategori \\
\hline \multirow{9}{*}{$\begin{array}{l}\text { Efektivitas } \\
\text { Penerapan } \\
\text { pembelajaran daring } \\
\text { dengan platform } \\
\text { google classroom } \\
\text { pada mata pelajaran } \\
\text { PJOK }\end{array}$} & Aktivitas & Pemanfaatan waktu & $74,3 \%$ & \multirow{3}{*}{$70,8 \%$} & \multirow{3}{*}{ Efektif } \\
\hline & peserta didik & $\begin{array}{l}\text { Lingkungan } \\
\text { pembelajaran }\end{array}$ & $69,2 \%$ & & \\
\hline & \multirow{4}{*}{$\begin{array}{l}\text { Pengelolaan } \\
\text { pembelajaran }\end{array}$} & $\begin{array}{l}\text { Sarana dan prasarana } \\
\text { pembelajaran }\end{array}$ & $68,5 \%$ & & \\
\hline & & $\begin{array}{l}\text { Kegiatan } \\
\text { pendahuluan } \\
\text { pembelajaran }\end{array}$ & $76,7 \%$ & \multirow{4}{*}{$75,6 \%$} & \multirow{4}{*}{ Efektif } \\
\hline & & $\begin{array}{l}\text { Kegiatan inti } \\
\text { pembelajaran }\end{array}$ & $74,6 \%$ & & \\
\hline & & $\begin{array}{l}\text { Kegiatan penutup } \\
\text { pembelajaran }\end{array}$ & $75,6 \%$ & & \\
\hline & \multirow{3}{*}{$\begin{array}{l}\text { Ketuntasan } \\
\text { pembelajaran }\end{array}$} & Media pembelajaran & $74,9 \%$ & & \\
\hline & & Evaluasi & $73,7 \%$ & \multirow[b]{2}{*}{$76,3 \%$} & \multirow[b]{2}{*}{ Efektif } \\
\hline & & $\begin{array}{l}\text { pembelajaran } \\
\text { Penguasaan Materi }\end{array}$ & $78,9 \%$ & & \\
\hline Nilai Persentase tot & & & $73,5 \%$ & & Efektif \\
\hline
\end{tabular}


Table 3. Ketuntasan Minimal Peserta Didik

\begin{tabular}{ccc}
\hline Keterangan & Jumlah peserta didik & Persentase \\
\hline Tuntas & 81 & $75,7 \%$ \\
Tidak tuntas & 26 & $24,3 \%$ \\
\hline
\end{tabular}

Berdasarkan deskripsi frekuensi dapat didefinisikan tanggapan responden terhadap item-item pernyataan variabel efektifitas penerapan pembelajaran daring dengan platform google classroom pada mata pelajaran PJOK dilihat dari proses pembelajaran dan nilai output peserta didik sebagai berikut. Dari tabel 2 diatas, dapat didefinisikan efektivitas penerapan pembelajaran daring dengan platform google classroom pada mata pelajaran PJOK dilihat dari proses pembelajaran yang terdiri dari 3 aspek yaitu aktivitas peserta didik, pengelolaan pembelajaran dan ketuntasan pembelajaran sebagai berikut.

\section{Aktivitas peserta didik}

Aktivitas peserta didik pada pembelajaran daring dengan platform google classroom dalam mata pelajaran PJOK di SMA Negeri 3 Singaraja memperoleh nilai persentase sebesar 70,8\% ada pada kategori efektif dilihat dari indikator pemanfaatan waktu peserta didik dimana peserta didik tepat waktu dalam mengikuti pembelajaran, peserta didik dapat mengakses materi pembelajaran PJOK kapan saja dan di mana saja dengan platform google classroom dan peserta didik selalu tepat waktu dalam mengumpulkan tugas pembelajaran PJOK. Dilihat dari indikator lingkungan belajar peserta didik dimana keluarga peserta didik mendukung untuk mengikuti pembelajaran daring dengan platform google classroom, peserta didik tidak mengalami masalah koneksi internet dalam mengumpulkan tugas subjek PJOK dengan platform google classroom dan peserta didik tidak merasa terganggu dengan adanya sistem pembelajaran daring dengan platform google classroom. Dilihat dari indicator sarana dan prasarana dimana fasilitas pembelajaran (handphone) dalam pembelajaran PJOK cukup memadai, lembar kerja pesrta didik sangat membantu dalam proses pembelajaran daring dan sarana dan prasarana olahraga yang dimiliki peserta didik cukup memadai.

\section{Pengelolaan Pembelajaran}

Pengelolaan pembelajaran daring dengan platform google classroom dalam mata pelajaran PJOK di SMA Negeri 3 Singaraja memperoleh nilai persentase sebesar 75,6\% dapat dikatakan efektif, dilihat dari indikator kegiatan pembelajaran awal dimana guru telah memulai pembelajaran dengan mengucapkan salam, berdoa, melakukan presensi, menjelaskan tujuan pembelajaran dan guru mengajukan pertanyaan yang berhubungan dengan pengetahuan sebelumnya dengan materi yang akan diberikan. Dilihat dari indikator kegiatan pembelajaran inti di mana guru telah menerapkan model inovativ, metode, strategi pembelajaran dan guru telah menyampaikan tugas gerakan belajar PJOK dan guru telah memberikan umpan balik pada platform kelas google. Dilihat dari indikator penutupan kegiatan dimana guru memberikan kesempatan bagi peserta didik untuk menyampaikan pengalaman belajar peserta didik melalui platform google classroom, peserta didik menyampaikan rangkuman pembelajaran melalui platform google classroom. Pengelolaan pembelajaran daring dengan platform google classroom dalam mata pelajaran PJOK di SMA Negeri 3 Singaraja dapat dikatakan efektif. Dilihat dari indikator kegiatan pembelajaran awal dimana guru telah memulai pembelajaran dengan mengucapkan salam, berdoa, hadir, menjelaskan tujuan pembelajaran dan guru mengajukan pertanyaan yang berhubungan dengan pengetahuan sebelumnya dengan materi yang akan diberikan. Dilihat dari indikator kegiatan pembelajaran inti di mana guru telah menerapkan model inovativ, metode, strategi pembelajaran dan guru telah menyampaikan tugas gerakan belajar PJOK dan guru telah memberikan umpan balik pada platform kelas google. Dilihat dari indikator penutupan kegiatan dimana guru memberikan kesempatan bagi peserta didik untuk menyampaikan pengalaman belajar peserta didik melalui platform google classroom, peserta didik menyampaikan rangkuman pembelajaran melalui platform google classroom. Guru menyampaikan rencana kegiatan belajar untuk pertemuan berikutnya mereka melalui platform google classroom dan guru menutup pembelajaran dengan doa melalui platform google classroom. Dilihat dari indikator media pembelajaran di mana google classroom memudahkan peserta didik untuk mengikuti pembelajaran PJOK secara online, platform google classroom mudah diakses dan tampilan google classroom sangat jelas.

\section{Ketuntasan pembelajaran}

Dilihat dari aspek ketuntasan pembelajaran, pembelajaran daring dengan platform google classroom pada mata pelajaran PJOK di SMA Negeri 3 Singaraja memperoleh nilai persentase sebesar 76,3 dapat dikatakan efektif, dilihat dari indikator evaluasi pembelajaran dimana peserta didik lebih mudah 
mengumpulkan tugas berupa dokumen, video, tentang mata pelajaran PJOK dengan platform google classroom dan tugas yang diberikan oleh guru sesuai dengan materi pembelajaran yang diberikan pada platform google classroom. Dilihat dari indicator penguasaan materi dimana peserta didik dapat mengerjakan tugas dengan baik, dapat mengerjakan soal ulangan harian dengan baik dan dapat mengerjakan soal penilaian akhir semester dengan baik. Indicator pemahaman materi juga dapat dibuktikan dengan tabel 3 diatas bahwa efektifitas penerapan pembelajaran daring dengan platform google classroom dilihat dari nilai output peserta didik yang diambil dari nilai Penilaian akhir semester genap peserta didik sebanyak 81 peserta didik memenuhi criteria ketuntasan minimal dan 21 orang tidak memenuhi criteria ketuntasan minimal. Nilai persentase ketuntasan minimal peserta didik adalah $(75,7 \%$ tuntas) jika dikonversikan pada tabel kriteria kefektifan ada pada katagori efektif.

Dari pemaparan diatas bahwa penerapan pembelajaran daring dengan platform google classroom pada mata pelajaran PJOK di SMA Negeri 3 Singaraja tahun pelajaran 2020/2021 dilihat dari proses pembelajaran mendapat nilai persentase sebesar 73,5 \% jika dikonversikan ada pada katagori efektif dan nilai output peserta didik sebesar (75,7\% tuntas) jika dikonversikan ada pada katagori efektif. Maka dapat disimpulkan bahwa penerapan pembelajaran daring dengan platform google classroom pada mata pelajaran PJOK di SMA Negeri 3 Singaraja dapat dikatakan efektif. Hasil dari penelitian ini sejalan dengan Penelian oleh (Ernawati, 2018) menyatakan bahwa penggunaan google classroom berpengaruh positif terhadap kualitas pembelajaran pada mata pelajaran ekonomi. Penelitian oleh (Dyah Purnama Sari, 2020), menyatakan bahwa pemanfaatan teknologi informasi pada pembelajaran jarak jauh selama pandemi covid-19 di SMP Negeri 4 Pekem dinilai efektif oleh siswa ditinjau dari pemahaman materi dan penguasaan aplikasi.penelitian oleh (Destyana \& Surjanti, 2021) menyatakan bahwa penggunaan google classroom dapat digunakan secara efektif dalam kegiatan belajar mengajar dengan presentase $76,42 \%$. Kemudian efektifitas google classroom dan motivasi belajar mempengaruhi hasil belajar secara positif dan signifikan. Penelitian oleh (Sa'diyah, H., Hastuti, A. F., \& Prasetiyo, 2020), menyatakan bahwa bahwa Google Classroom terbukti efektif dalam mengurangi dampak negatif pembelajaran PPKn, yang terlihat dalam beberapa bentuk. Pertama, survei kepuasan penggunaan Google Classroom dari sudut pandang siswa mengungkapkan bahwa mereka merasa LMS ini efektif dalam penyampaian materi, pemberian tugas, dan kemudahan akses dan penggunaan. Penelitian oleh (Nainggolan \& Manalu, 2021) menyatakan bahwa Terdapat pengaruh positif dan signifikan penggunaan google classroom terhadap efektifitas pembelajaran dengan nilai sebesar 0.244. Penelitian oleh (Palopo, 2021) menyatakan bahwa pembelajaran menggunakan Google Classroom cukup efektif pada variabel kemudahan memahami materi dengan nilai rata-rata 3,68. Variabel fleksibilitas waktu belajar berada pada kategori efektif dengan nilai rata-rata 4,14. Sedangkan Variabel kejelasan instruksi dan tercapainya sasaran pembelajaran berada pada kategori efektif dengan nilai rata-rata 4,27.

\section{SIMPULAN DAN SARAN}

Berdasarkan hasil analisis data dapat disimpulkan penerapan pembelajaran daring dengan platform google classroom pada mata pelajaran PJOK di SMA Negeri 3 Singaraja tahun pelajaran 2020/2021 dilihat dari proses pembelajaran dengan aspek aktivitas pesertadidik, pengelolaan pembelajaran dan ketuntasan pembelajaran mendapat nilai persentase sebesar 73,5 \% jika dikonversikan ada pada katagori efektif dan nilai output peserta didik yang diambil dari nilai ulangan akhir semester genap sebesar $(75,7 \%$ tuntas $)$ jika dikonversikan ada pada katagori efektif. Maka dapat disimpulkan bahwa penerapan pembelajaran daring dengan platform google classroom pada mata pelajaran PJOK di SMA Negeri 3 Singaraja dapat dikatakan efektif. Hasil penelitian ini diharapkan bisa dijadikan sebagai tolak ukur untuk mengetahui efektivitas penerapan pembelajaran daring dengan platform google classroom pada mata pelajaran PJOK di SMA Negeri 3 Singaraja dan Dengan penelitian ini dapat digunakan sebagai acuan bagi sekolah dan guru untuk mengontrol efektivitas penerapan pembelajaran daring dengan platform google classroom pada mata pelajaran PJOK di SMA Negeri 3 Singaraja.

\section{DAFTAR RUJUKAN}

Destyana, V. A., \& Surjanti, J. (2021). Efektivitas Penggunaan Google Classroom dan Motivasi Belajar Terhadap Hasil Belajar Peserta Didik Mata Pelajaran Ekonomi. Edukatif: Jurnal Ilmu Pendidikan, 3(3), 1000-1009. https://edukatif.org/index.php/edukatif/index.

Dyah Purnama Sari, P. S. (2020). Efektivitas Pembelajaran Jarak Jauh Dengan Daring Selama Pandemi Covid-19 Mata Pelajaran Pendidikan Jasmani Olahraga Dan Kesehatan (PJOK). Pediatric Critical Care Medicine, 1022-1023. https://doi.org/10.1097/PCC.0000000000002513.

Ernawati. (2018). Pengaruh Penggunaan Aplikasi Google Classroom Terhadap Kualitas Pembelajaran dan 
Hasil Belajar Siswa Pada Mata Pelajaran Ekonomi Kelas IX di MAN 1 Kota Tanggerang Selatan. Skripsi : Fakultas Ilmu Tarbiyah dan Keguruan . Universitas Islam Negeri Syarif Hid.

Habibi, A. W. (2020). Dalam Pembelajaran Pendidikan Jasmani Mi Darwata Kalijaran Maos Cilacap Program Studi Pendidikan Guru Madrasah Ibtidaiyah.

Kanca, I. N., \& Wijaya, M. A. (2018). Buku Ajar Paradikma Baru Pembelajaran PJOK. Undiksha Press.

Kemendikbud. (2017). Pendidikan Jasmani, Olahraga dan Kesehatan. Jakarta: Pusat Kurikulum dan Perbukuan.

Maesaroh, S., Hasna, A., DR, Y., \& ZN, F. (2019). Penerapan Metode Cooperative Learning dengan Memanfaatkan Aplikasi Google Classroom sebagai Upaya Meningkatkan Nilai Karakter Kebaikan Siswa Menengah Pertama. Prosiding Konferensi Pendidikan Nasional, 168-172.

Mashud, M. (2019). Analisis Masalah Guru Pjok Dalam Mewujudkan Tujuan Kebugaran Jasmani. Multilateral Jurnal Pendidikan Jasmani Dan Olahraga, 17(2), 77-85. https://doi.org/10.20527/multilateral.v17i2.5704.

Mohammad Yazdi. (2012). E-learning sebagai Media Pembelajaran Interaktif Berbasis teknologi Informasi. Jurnal Ilmua Foristek, 2 (1)(1), 143-152.

Nainggolan, A. P., \& Manalu, R. B. B. (2021). Pengaruh Penggunaan Google Classroom Terhadap Efektifitas Pembelajaran. Journal Coaching Education Sports, 2(1), 17-30. https: //doi.org/10.31599/jces.v2i1.515.

Nirfayanti, N., \& Nurbaeti, N. (2019). Pengaruh Media Pembelajaran Google Classroom Dalam Pembelajaran Analisis Real Terhadap Motivasi Belajar Mahasiswa. Proximal Jurnal Penelitian Matematika Dan Pendidikan Matematika ISSN 26158132 (Cetak) ISSN 26157667 (Online), 2(1), 5059. https://e-journal.my.id/proximal/article/view/211.

Palopo, U. C. (2021). Efektivitas Pembelajaran Daring Menggunakan Google Classroom pada Mata Kuliah Logika Informatika. 1(2), 102-107.

Prasetya, T. A., \& Harjanto, C. T. (2020). Pengaruh mutu pembelajaran online dan tingkat kepuasan mahasiswa terhadap hasil belajar saat pandemi Covid19. Pendidikan Teknologi Dan Kejuruan, $17(2), 188-197$.

Pujiasih, E. (2020). Membangun Generasi Emas Dengan Variasi Pembelajaran Online Di Masa Pandemi Covid-19. Ideguru: Jurnal Karya Ilmiah Guru, 5(1), 42-48. https://doi.org/10.51169/ideguru.v5i1.136.

Pujilestari, Y. (2020). Dampak Positif Pembelajaran Online Dalam Sistem Pendidikan Indonesia Pasca Pandemi Covid-19. Adalah, 49-56. http://journal.uinjkt.ac.id/index.php/adalah/article/view/15394/7199.

Puspitasari, E., Setyosari, P., \& Amirudin, A. (2016). Peningkatan Motivasi Dan Hasil Belajar Melalui Think Pair Share (Tps) Di Sekolah Dasar. Jurnal Pendidikan - Teori, Penelitian, Dan Pengembangan, 1(7), 1432-1436. https://doi.org/10.17977/jp.v1i7.6589.

Sa'diyah, H., Hastuti, A. F., \& Prasetiyo, W. H. (2020). Efektivitas Google Classroom dalam Pengelolaan Pembelajaran Masa Pandemi di SMA Negeri 1 Wonosari. 3, 120-125. https: //doi.org/10.23917/blbs.v3i1.13893.

Syah, R. H. (2020). Dampak Covid-19 pada Pendidikan di Indonesia: Sekolah, Keterampilan, dan Proses Pembelajaran. SALAM: Jurnal Sosial Dan Budaya Syar-I, 7(5). https://doi.org/10.15408/sjsbs.v7i5.15314.

Wicaksono, M. D. (2020). Pemanfaatan Google Classroom Dalam Srategi Pembelajaran Kooperatif Pada Mata Pelajaran Ips Kelas VIII. Jurnal Ilmu Ilmu Sosial, 17(1), 234-242.

Wulandari, O. I. H. dan S. S. (2018). Daring to draw causal claims from non-randomized studies of primary care interventions. Family Practice, 35(5), 639-643. https://doi.org/10.1093/fampra/cmy0 05. 